\title{
MEMORIAL
}

\section{MIKHAIL SEMENOVICH MESEZHNIKOV (1932-1989)}

An outstanding Soviet geologist, stratigrapher, and paleontologist, M. S. Mesezhnikov, aged 57, passed away on February 27, 1989, in Leningrad. He was the leader in the studies on the Jurassic system of the USSR. His broad scientific interests covered the problems of regional and general stratigraphy and interregional correlation, the Boreal Jurassic ammonoids, and the theory and practical use of zonal stratigraphy, including its application to petroleum geology. All this was reflected in his numerous (over 200) and widely known scientific publications.

In the last years, M. S. Mesezhnikov was at the head of the Jurassic Commission of the Interdepartmental Stratigraphic Committee of the USSR (ISC). He took an active part in the work of international groups on the Jurassic stratigraphy and the Jurassic-Cretaceous boundary.

M. S. Mesezhnikov was an excellent friend and a thoughtful leader for many stratigraphers and paleontologists. His death is a tragic loss which will be felt for a very long time.

\author{
G. Ya. Krymholts \\ Professor \\ Honorary Chairman of the \\ Jurassic Commission of the \\ ISC of the USSR
}

\section{PALEONTOLOGICAL SOCIETY}

\section{CANDIDATES FOR OFFICE, 1990 ANNUAL BALLOT}

At its midyear in Cheney, Washington, on 7 May 1989, Council of The Paleontological Society selected the following candidates for Society offices from nominees proposed by the Nominating Committee:

For:

President-Elect (1990-91): Roger L. Kaesler, Lawrence, Kansas

Trasurer (1990-93): June R. P. Ross, Bellingham, Washington

Councilor Unrestricted (1990-92): Steven M. Stanley, Baltimore, Maryland

Co-editor, Paleobiology (1990-92): Geerat J. Vermeij, Davis, California

This slate will be submitted to the Membership on the Annual Ballot in August, 1990. Additional nominations made in accordance with provisions of Section 3, Chapter 2 of the By-Laws will be accepted by the Secretary until 1 July 1990, and will be included as special tickets with the regular ticket announced above.

Donald L. Wolberg Secretary 